\title{
Penerapan Quick Response (QR) Code pada Aplikasi Electronic-Invitation (E-Invitation)
}

\author{
Nurwanto, Gus Nanang Syaifuddiin, Fitayani Intan Pradani \\ Program Studi Teknik Informatika, Fakultas Teknik, Universitas Muhammadiyah Ponorogo \\ Jl. Budi Utomo No. 10, Ponorogo, Indonesia Telp. (0352) 481124 \\ e-mail: nurwanto@umpo.ac.id, gus nanang@umpo.ac.id, fita.prada@gmail.com
}

\begin{abstract}
Abstrak
Quick Response Code atau QR Code adalah semacam simbol dua dimensi yang diperuntukkan data berkapasitas besar dan dapat menampung lebih banyak informasi, serta memungkinkan kontennya diterjemahkan dengan kecepatan tinggi. Tujuan pada penelitian ini yaitu menerapkan $Q R$ Code pada perancangan aplikasi Electronic Invitation (E-Invitation) berbasis web karena $Q R$ Code memiliki kapasitas data yang dapat disimpan lebih banyak dibandingan dengan Barcode. QR Code digunakan untuk menyimpan data berupa NIK dan nama lengkap yang telah dienskripsi ke MD5 sebagai pembeda antara orang satu dengan yang lainnya, serta untuk menggantikan pengisian daftar hadir secara konvensional menggunakan kertas pada saat acara dilaksanakan serta mempercepat dalam melakukan verifikasi dan rekapitulasi data kehadiran. Pengujian dilakukan dengan menggunakan metode Black Box dari 12 fitur yang ada pada aplikasi E-Invitation diantaranya Register, Login Tamu, Mengubah Biodata Tamu, Mengunduh Undangan, Login Administrator, Dashboard, Absensi, Daftar Hadir, Daftar Tamu Tidak Hadir, Acara, Data Tamu, Data User. Hasil pengujian menunjukan semua fitur dapat berfungsi dengan baik dan tidak ada bug yang ditemukan.
\end{abstract}

Kata kunci: Quick Response Code, Web, PHP, Black Box

\begin{abstract}
Quick Response Code or QR Code is a kind of two-dimensional symbol intended for large-capacity data and can hold more information, and allows the content to be translated at high speed. The purpose of this research is to apply the QR Code on a web-based Electronic Invitation (E-Invitation) application, because the QR Code has higher capacity of data that can be stored than Barcodes. The QR Code is used to store the data in the form of identity numbers and full names that have been encrypted into MD5 as a differentiator among each other, and to replace filling in conventional attendance lists using paper during an event and accelerate the verification and recapitulation of attendance data. The testing is done using the Black Box method of 12 features in the E-Invitation application, including Register, Guest Login, Changing Guests' Profiles, Downloading Invitations, Administrator Login, Dashboard, Attendance, Attendance List, Absent Guest List, Events, Guest Data, and User Data. The test results show all features can function properly and no bugs are found.
\end{abstract}

Keywords: Quick Response Code, Web, PHP, Black Box

\section{Pendahuluan}

Perkembangan teknologi informasi dan komunikasi memberikan pengaruh yang signifikan dalam peningkatan kualitas hidup manusia. Efisiensi, digitalisasi, dan otomatisasi merupakan tuntutan yang harus tersedia di era revolusi industri 4.0, bagi yang mampu mengimplementasikan teknologi informasi dan komunikasi di berbagai bidang akan dapat bertahan dan mengalahkan kompetitornya. Perkembangan teknologi informasi dan komunikasi membuktikan akan keberadaanya sebagai media pengantar pesan harapan dan keinginan manusia dalam upaya merealisasikan tujuan dan mengatasi permasalahan berbagai aspek kehidupan. Salah satu contohnya dalam melakukan transaksi jual beli pada sebuah swalayan, konsumen memilih barang yang dibeli dengan mengambil sendiri setelah itu diserahkan kepada kasir untuk dilakukan pencatatan transaksi. Kasir meng-input-kan produk yang dibeli konsumen dengan cara memindai kode batang atau Barcode yang ada disetiap kemasan produk 
menggunakan alat yang disebut Barcode Scanner. Pemindaian dilakukan dengan cepat, kemudian nama produk dan harga secara otomatis masuk ke dalam aplikasi yang digunakan kasir untuk mencatat transaksi. Dengan adanya Barcode pada setiap kemasan produk menjadikan kemudahan dalam pencatatan transaksi.

Barcode dapat didefinisikan sebagai optik, dapat dibaca oleh mesin, dan secara grafis disajikan dalam bentuk gambar dari sebuah set data yang digunakan untuk mengenali produk. Banyak informasi dapat dikodekan dalam Barcode melalui format kode visual unik yang disusun untuk mewakili 12 digit data dengan gambar garis-garis hitam yang berdekatan dengan lebar dan ruang variabel yang dapat diidentifikasi oleh mesin seperti pemindai laser atau smartphone [1]. Kekurangan Barcode yaitu jika digunakan untuk menampung data dengan kapasitas besar maka Barcode yang dihasilkan sangat panjang sesuai dengan data yang ditampung karena berbentuk bar atau batang. Quick Response Code sering disebut $Q R$ Code adalah semacam simbol dua dimensi yang diperuntukkan data berkapasitas besar dan bisa menyimpan informasi lebih besar daripada Barcode. QR atau Quick Response dapat menterjemahkan dengan cepat konten atau data yang disimpan di dalamnya [2].

Tujuan pada penelitian ini yaitu menerapkan $Q R$ Code pada perancangan Electronic Invitation (E-Invitation) berbasis web. $Q R$ Code digunakan karena aplikasi ditujukan untuk penggunaan data yang cukup besar, terdiri NIK dan nama lengkap sebagai pembeda antara orang satu dengan yang lainnya. E-Invitation dirancang untuk menggantikan pengisian daftar hadir menggunakan kertas pada saat acara dilaksanakan dan mempercepat dalam melakukan verifikasi dan rekapitulasi data kehadiran.

Penelitian mengenai penerapan $Q R$ Code pernah dilakukan untuk verifikasi sertifikat. Verifikasi sertifikat dilakukan untuk memeriksa keabsahan sertifikat yang telah diterbitkan serta menghindari penggandaan sertifikat. Model Prototype digunakan pada proses pengembangan perangkat lunak dan menggunakan framework PHP yaitu Laravel. Evaluasi sistem dilakukan menggunakan System Usability Scale (SUS) berupa kuesioner yang melibatkan 40 responden dengan nilai rata-rata 83,33 [3]. Perbedaanya dengan penelitian yang dilakukan yaitu pada penerapan $Q R$ Code dan testing sistem. Penerapan $Q R$ Code pada aplikasi E-Invitation digunakan untuk menampung data yang terdiri dari NIK dan nama lengkap tamu yang dienskripsi ke MD5 serta digunakan untuk verifikasi pada saat kehadiran tamu. Aplikasi yang selesai dirancang diuji dengan metode Black Box untuk memastikan setiap fitur berjalan sesuai yang diharapkan.

\section{Metodologi Penelitian}

Pengumpulan data dilakukan menggunakan metode penelitian lapangan dengan mencari dokumen yang berhubungan dengan perancangan aplikasi E-Invitation seperti data acara yang pernah dilaksanakan, data tamu dan daftar hadir tamu dalam bentuk kertas. Pengumpulan data juga dilakukan melalui sumber yang lainnya seperti buku ataupun pencarian dari internet. Semua data yang diperoleh selanjutnya diolah dengan mempertimbangkan beberapa faktor diantaranya waktu penelitian dan biaya implementasi dengan harapan pengolahan data tersebut memberikan luaran berupa hasil percobaan dari hipotesa yang teruji dan memiliki nilai tepat guna bagi masyarakat Indonesia.

Metode perancangan perangkat lunak yang digunakan adalah Model Prototype dengan 3 tahapan yaitu:

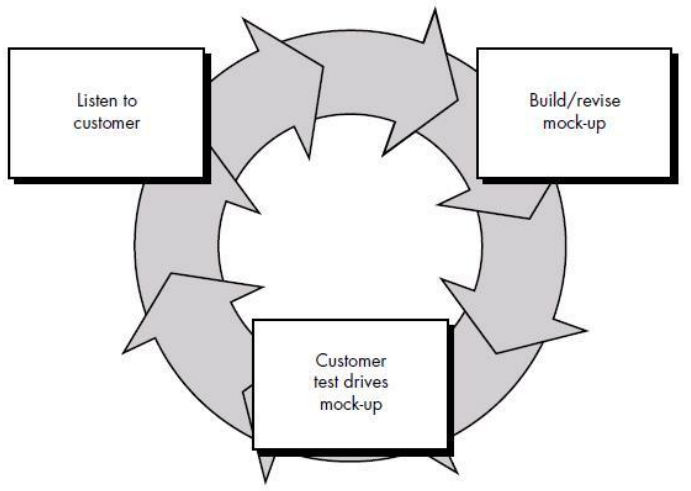

Gambar 1. Prototype Model [4] 
Tahap pertama dari model Prototype berdasarkan Gambar 1 yaitu listen to customer, pada tahapan dilakukan pengumpulan data untuk menganalisa kebutuhan sistem seperti hardware, software dan fitur pada aplikasi E-Invitation. Tahap kedua yaitu build/revise mock-up, pada tahap ini dilakukan membuat prototype aplikasi sesuai dengan kebutuhan yang diperoleh dari tahap pertama. Perancangan aplikasi dilakukan menggunakan bahasa pemrograman PHP versi 7 serta DBMS MySQL. Tahap ketiga atau tahap terakhir dari metode Prototype yaitu customer test drives mock-up, penulis melakukan pengujian sistem menggunakan Metode Black Box.



Gambar 2. Gambaran Umum Sistem

Gambar 2 diatas merupakan gambaran umum dari aplikasi E-Invitation. Aplikasi dimulai dari pengecekan apakah sudah memiliki akun atau belum, jika belum memiliki akun maka diwajibkan untuk melakukan registrasi terlebih dahulu dengan memasukkan beberapa data yang ada pada form registrasi. Setelah melakukan pendaftaran, tamu bisa login dengan memasukkan nomor identitas dan password, pada proses login sistem melakukan validasi nomor identitas dan password, jika data yang dimasukkan tersebut tidak sesuai atau tidak valid maka tamu diarahkan kembali ke halaman login untuk meng-input-kan ulang data. Tamu akan diarahkan ke halaman utama aplikasi jika data yang dimasukkan tersebut valid dan dapat mengunduh undangan. Akan tetapi, sebelum mengunduh undangan diharuskan memeriksa biodata yang telah di-input-kan, jika biodata belum sesuai maka tamu bisa melakukan perubahan data.

\section{Kajian Pustaka}

\subsection{Quick Response (QR) Code}

Quick Response Code sering disebut $Q R$ Code adalah semacam simbol dua dimensi yang awalnya digunakan untuk melacak inventaris dalam pembuatan suku cadang kendaraan dan sekarang digunakan diberbagai industri. QR atau Quick Response memungkinkan kontennya diterjemahkan dengan kecepatan tinggi. $Q R$ Code adalah kode matriks yang 
dikembangkan dan dirilis terutama agar mudah dibaca oleh pemindai. $Q R$ Code menampung banyak informasi dan juga memiliki kemampuan koreksi kesalahan. Data dapat dipulihkan bahkan ketika bagian kode rusak [2]. $Q R$ Code biasanya digambarkan dalam bentuk persegi putih kecil dengan bentuk geometris hitam seperti pada Gambar 3, walaupun untuk saat ini $Q R$ Code banyak yang berwarna.

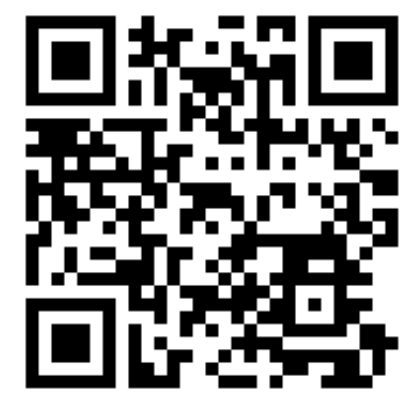

Gambar 3. Contoh QR Code

QR Code dapat menyimpan lebih banyak informasi daripada Barcode biasa. Informasi yang dikodekan dalam kode QR dapat berupa URL, nomor telepon, pesan SMS, V-card, atau teks apa pun [5]. Gambar 3 adalah contoh $Q R$ Code yang berisi data berupa teks "Universitas Muhammadiyah Ponorogo".

\section{$3.2 \quad$ Web}

Web adalah sekumpulan halaman yang membentuk suatu rangkaian bangunan, dimana setiap halaman saling terhubung pada jaringan halaman (hyperlink) yang memuat informasi secara dinamis maupun statis berupa teks, gambar, suara, animasi, video dan kombinasi dari semuanya [6]. Aplikasi web dianggap sebagai platform standar untuk memberikan informasi mengenai data dan untuk memberikan layanan melalui seluruh jaringan web. Aplikasi web digunakan diberbagai situs seperti perbankan, pendidikan, keuangan dan berita serta media sosial dan saluran televisi. Cara paling mendasar untuk mengumpulkan informasi tentang topik apa pun adalah dengan memanfaatkan aplikasi web dan hanya memerlukan koneksi internet untuk mengakses aplikasi seperti itu dari setiap lokasi [7].

\subsection{Hypertext Preprocessor}

Hypertext Preprocessor atau disingkat PHP adalah salah satu bahasa pemrograman open source yang digunakan untuk membuat sebuah aplikasi berbasis web dinamis. PHP merupakan bahasa pemrograman di sisi server atau server-side programming dimana pemrosesan semua data dilakukan pada server dan dapat digunakan untuk pengolahan data dalam format $X M L$. Saat ini versi terbaru PHP adalah 7.4.5 yang dapat diunduh melalui situs resminya yaitu https://www.php.net/ [8][9].

\section{$4 \quad$ Hasil dan Pembahasan}

Hasil dan Pembahasan menjelaskan cara pengoperasian fitur-fitur aplikasi serta pengujian aplikasi dengan menggunakan metode Black Box.

\subsection{Pembahasan Aplikasi}

Aplikasi E-Invitation memiliki fitur diantaranya adalah fitur Register, Dashboard Tamu dan fitur Konfirmasi Kehadiran.

\subsubsection{Fitur Register}

Fitur Register digunakan oleh tamu untuk registrasi serta memilih acara yang tersedia yang dapat diakses melalui https://invitation.ngelmu.net/register.php. Tamu diwajibkan untuk mengisi beberapa data seperti nomor identitas, nama lengkap, alamat, email, jabatan, nomor HP, password dan acara Pada Halaman Register. Nomor identitas dapat di-input-kan Nomor Induk Kependudukan atau NIK maupun nomor SIM, dan untuk password ada 2 masukan yang pertama yaitu password yang kedua konfirmasi password, jadi untuk kedua masukan ini harus sama, jika tidak sama maka registrasi tidak bisa dilanjutkan. Apabila data sudah lengkap dapat 
menekan tombol register pada bagian kanan bawah. Detail Halaman Register dapat dilihat pada Gambar 4.

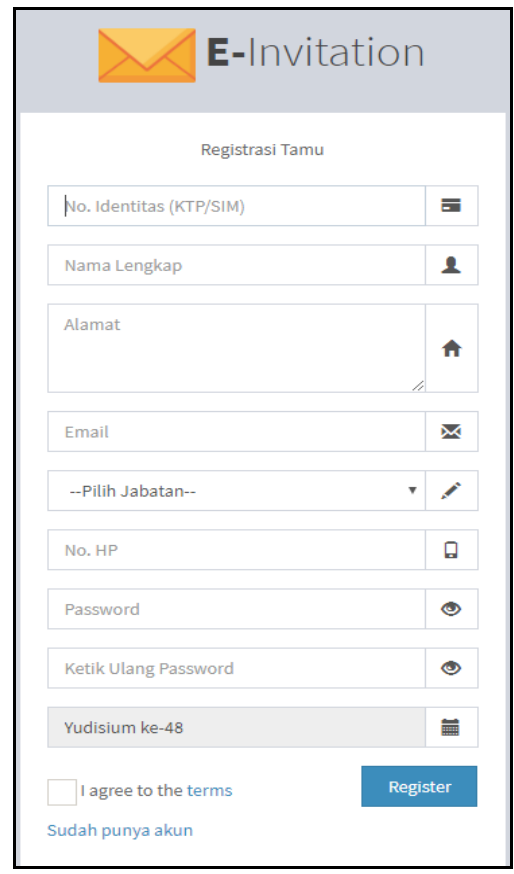

Gambar 4. Halaman Register

\subsubsection{Dashboard Tamu}

Dashboard tamu terdiri dari 2 bagian yaitu bagian kiri atau left sidebar menampilkan foto dan nama tamu serta di bawahnya terdapat dua menu yaitu dashboard dan keluar, bagian kanan atau content, menampilkan 2 fitur yaitu ubah biodata tamu dan unduh undangan.

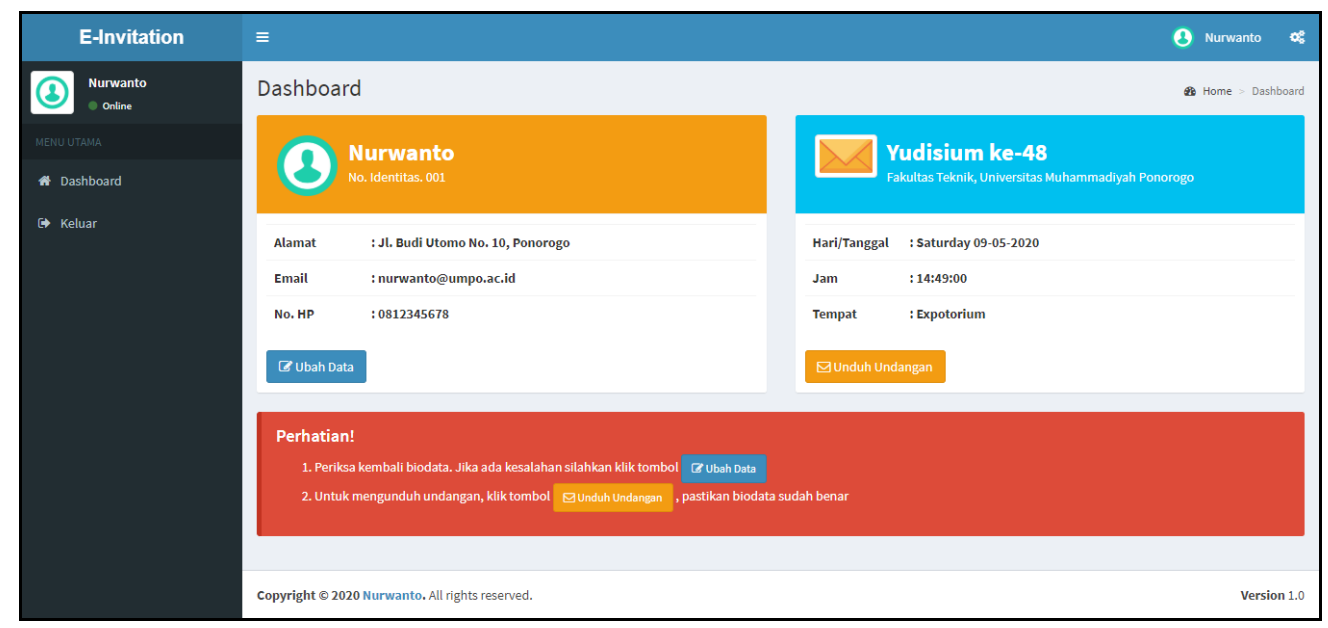

Gambar 5. Dashboard Tamu

Fitur unduh undangan berfungsi untuk mendapatkan undangan elektronik berupa PDF. Undangan diunduh dengan cara klik tombol "Unduh Undangan". Undangan berisi semua informasi mengenai acara yaitu nama acara, tempat, tanggal/waktu dan keterangan yang lainnya. Bagian terpenting dari undangan adalah $Q R$ Code yang menjadi kunci pada saat menghadiri acara. Isi dari $Q R$ Code merupakan hasil enskripsi MD5 dari NIK dan nama lengkap yang akan dipindai pada saat konfirmasi kehadiran. 


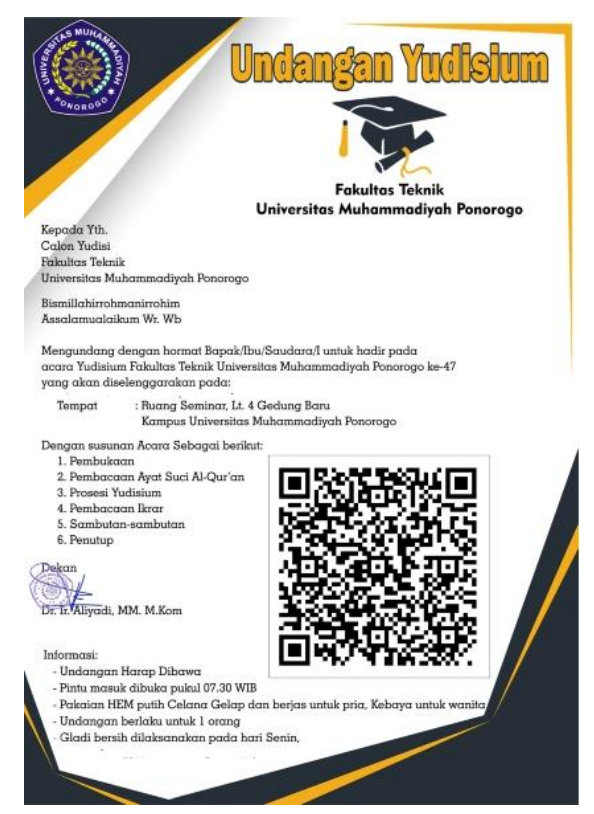

Gambar 6. Undangan Elektronik

\subsubsection{Halaman Konfirmasi Kehadiran}

Halaman Konfirmasi Kehadiran terdapat beberapa fitur yaitu form absensi, tata cara dan daftar kehadiran. Konfirmasi dilakukan dengan cara memindai $Q R$ Code yang ada pada undangan elektronik. Apabila data yang dipindai sesuai maka secara otomatis nama dan alamat akan terisi sesuai dengan data yang diinputkan oleh tamu. Cara menyimpan daftar hadir bisa dilakukan dengan dua cara yaitu tekan Enter atau tekan tombol Simpan.

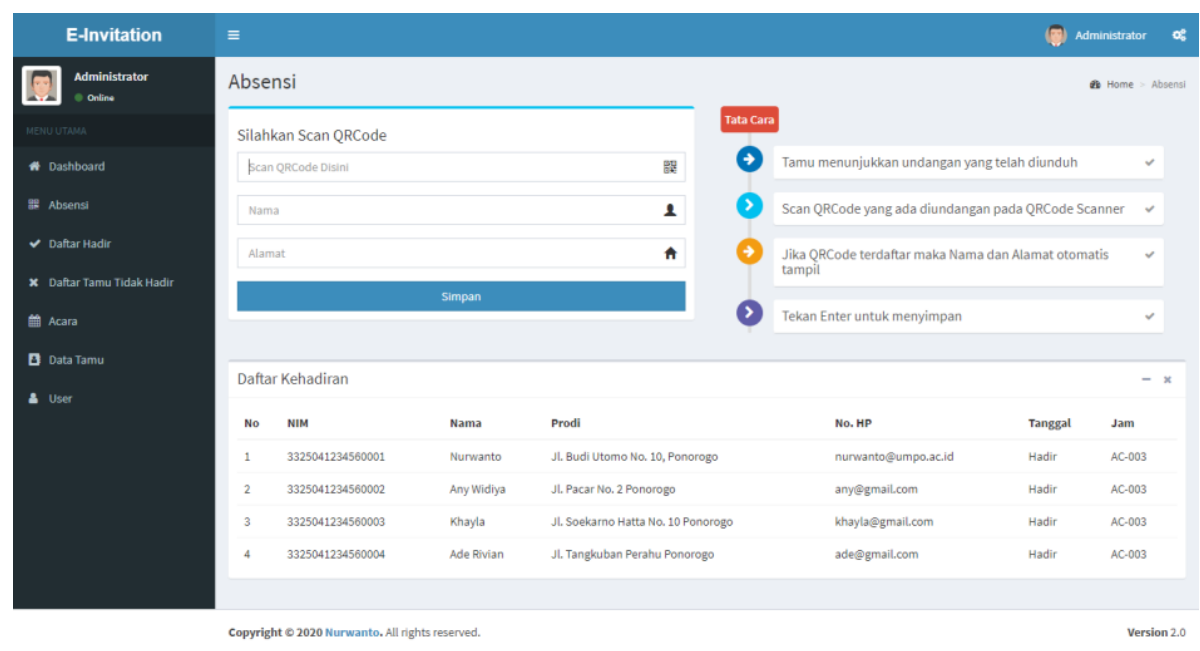

Gambar 7. Halaman Konfirmasi Kehadiran

\subsection{Pengujian Aplikasi}

Aplikasi yang selesai dirancang diuji dengan metode Black Box dari 12 fitur yang ada pada aplikasi E-Invitation. Detail pengujian ditampilkan pada Table 1.

\begin{tabular}{llll}
\multicolumn{5}{c}{ Table 1. Hasil Pengujian Aplikasi } \\
\hline No. & \multicolumn{1}{c}{ Fitur } & Kriteria Evaluasi Hasil Pengujian & Status \\
\hline 1 & Register & Sistem dapat menyimpan data tamu & Sukses \\
2 & Login Tamu & - Aplikasi dapat mengakses data tamu & Sukses \\
& & pada database dan memeriksa valid & \\
\hline
\end{tabular}




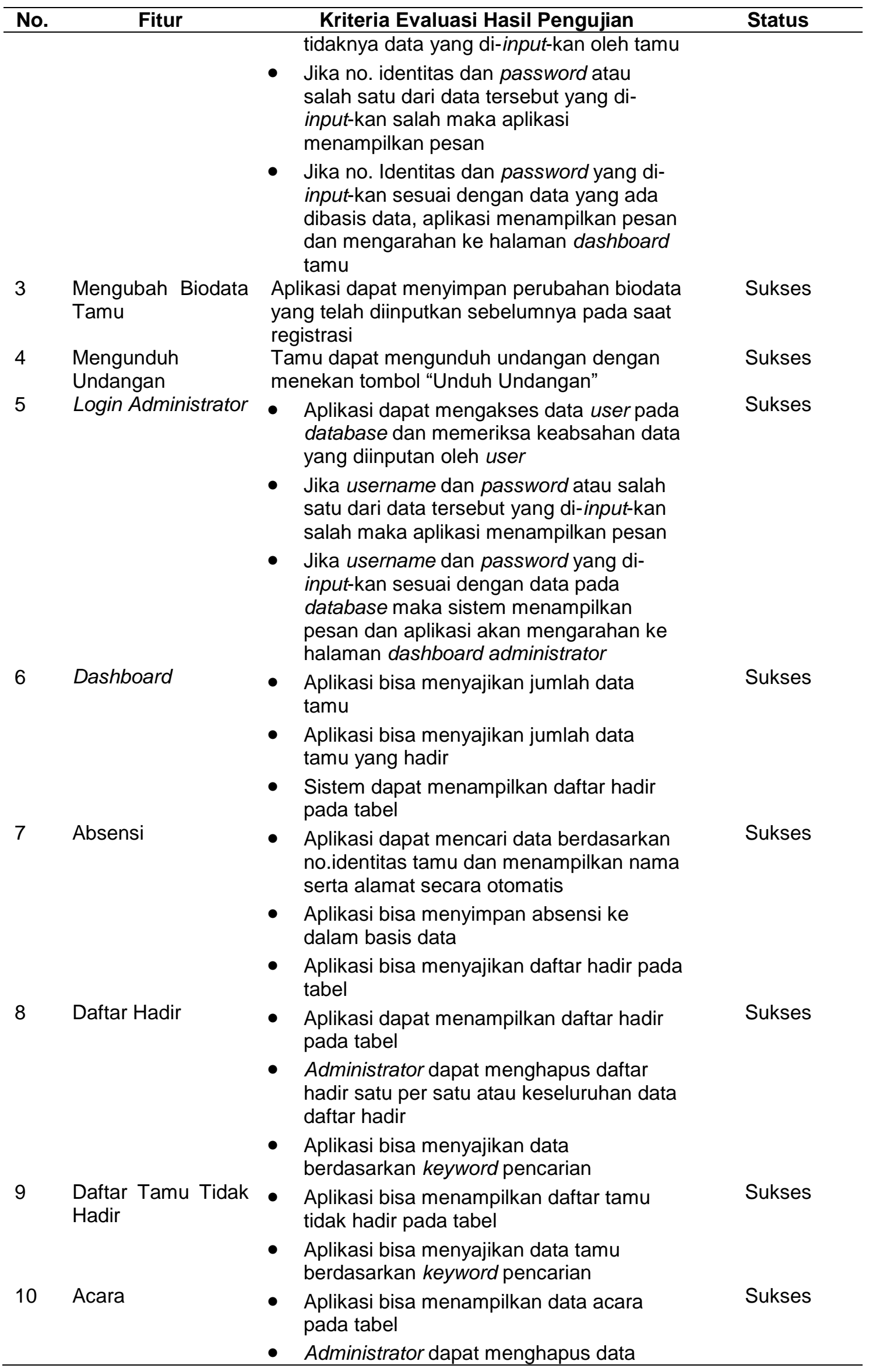




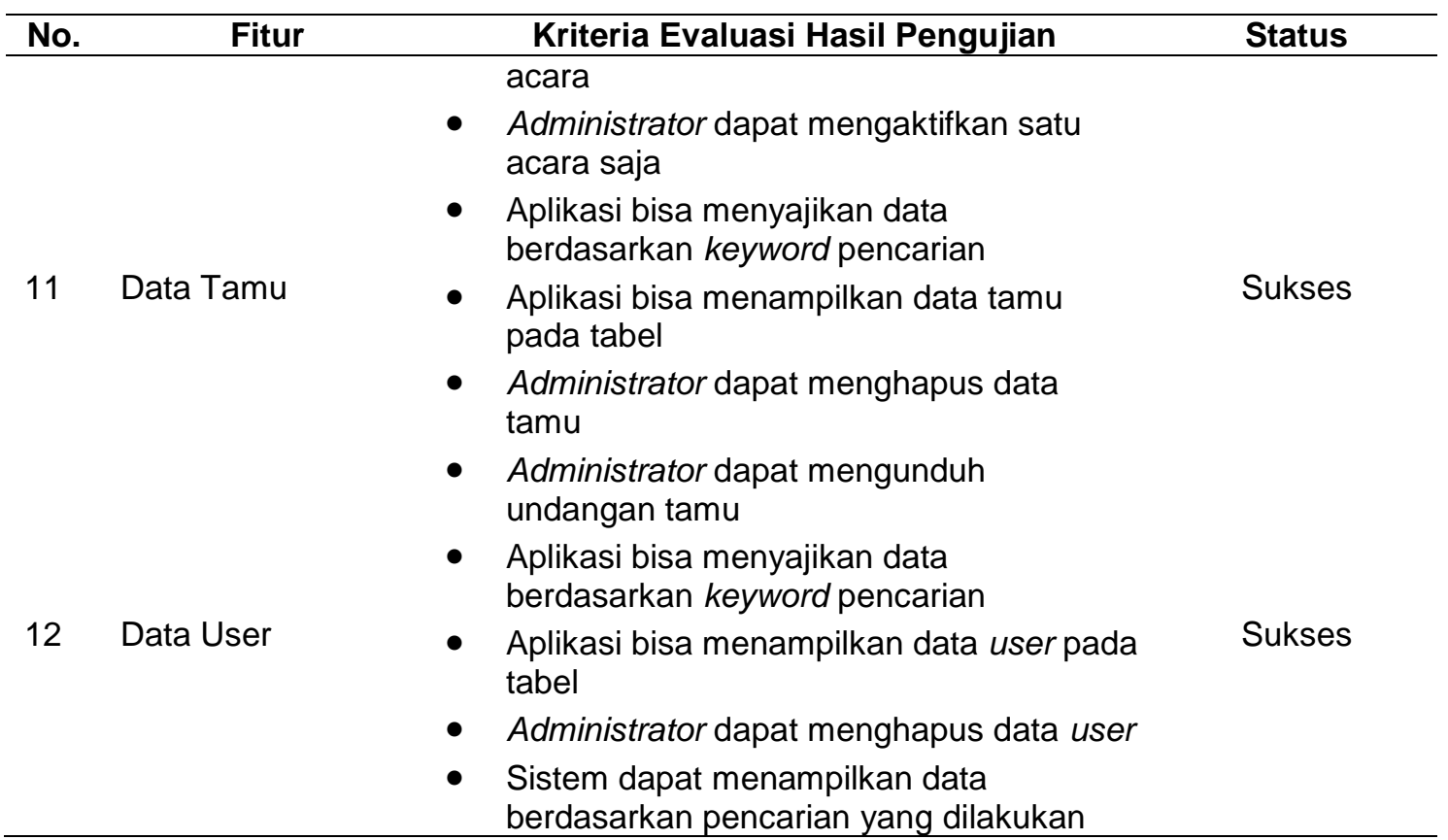

\section{Kesimpulan}

Aplikasi E-Invitation berbasis web dengan mengimplementasikan $\operatorname{Qr}$ Code, kapasitas data yang dapat disimpan lebih banyak dibandingan dengan Barcode. $Q R$ Code digunakan untuk menyimpan data berupa NIK dan nama lengkap yang telah dienskripsi ke MD5, serta lebih cepat dalam pemindaian menggunakan $Q R$ Code scanner Panda Model: PRJ-656. Pengujian yang dilakukan dengan menggunakan metode Black Box terdiri dari 12 fitur yang ada pada aplikasi E-Invitation diantaranya Register, Login Tamu, Mengubah Biodata Tamu, Mengunduh Undangan, Login Administrator, Dashboard, Absensi, Daftar Hadir, Daftar Tamu Tidak Hadir, Acara, Data Tamu, Data User. Hasil pengujian menunjukan semua fitur dapat berfungsi dengan baik dan tidak ada bug yang ditemukan.

\section{Daftar Pustaka}

[1] E. U. Chowdhury and A. Morey, "Intelligent Packaging for Poultry Industry," Poult. Sci. Assoc. Inc., vol. 28, pp. 791-800, 2019.

[2] M. Amrou, A. Boulmakoul, H. Badir, and A. Lbath, "A scalable real-time tracking and monitoring architecture for logistics and transport in RoRo terminals," Procedia Comput. Sci., vol. 151, no. 2018, pp. 218-225, 2019.

[3] E. Febriyanto, U. Rahardja, A. Faturahman, and N. Lutfiani, "Sistem Verifikasi Sertifikat Menggunakan Qrcode Pada Central Event Information," vol. 18, no. 1, pp. 50-63, 2019.

[4] R. S. Pressman, Rekayasa Perangkat Lunak (Pendekatan Praktisi) Edisi 7. Yogyakarta: Andi, 2012.

[5] R. Ashford, "QR codes and academic libraries Reaching mobile users," Coll. Res. Libr. News, vol. 71, no. November 2010, pp. 526-530, 2010.

[6] A. Hariyanto, Membuat Aplikasi Computer Based Test dengan PHP, MySQLi dan Bootstrap. Yogyakarta: Lokomedia, 2017.

[7] A. W. Marashdih, Z. F. Zaaba, K. Suwais, and N. A. Mohd, "Web Application Security: An Investigation on Static Analysis with other Algorithms to Detect Cross Site Scripting," Procedia Comput. Sci., vol. 161, pp. 1173-1181, 2019.

[8] N. Nurwanto, Pemrograman Dasar PHP \& MySQLi. Ponorogo: Unmuh Ponorogo Press, 2018.

[9] P. O. Yudiantara, I. M. Sukarsa, and N. P. Sutramiani, "Dashboard Executive Information System dengan Pendekatan Sistem Terdistribusi untuk Pemantauan," Merpati, vol. 7, no. 1, pp. 67-76, 2019. 